\title{
WOJNA JAKO REDAKTORKA: (PRZE)CZUCIA WOJENNE W MORELACH DONBASU LUBOW JAKYMCZUK
}

\author{
RYSZARD KUPIDURA \\ Uniwersytet imienia Adama Mickiewicza, Poznań — Polska \\ ryszardk@amu.edu.pl; ORCID: 0000-0003-4237-3828 \\ ВІЙНА ЯК РЕДАКТОР: \\ (ПЕРЕД)ЧУТТЯ ВІЙНИ В АБРИКОСАХ ДОНБАСУ ЛЮБОВІ ЯКИМЧУК \\ РИШАРД КУПІДУРА \\ Університет імені Адама Міцкевича, Познань - Польща
}

\begin{abstract}
АНОТАЦІЯ. Стаття присвячена літературознавчому аналізу поетичної збірки Любові Якимчук Абрикоси Донбасу (2015). Стверджується, що вихід у світ цієї збірки демонструє актуальну тематику творів сучасної української художньої літератури - це насамперед багатогранна репрезентація проблематики Донбасу. Вірші проаналізовано 3 огляду на такі аспекти, як конструювання часу, ставлення до традиції та сучасності. Усебічно розглянуто й автотематичні мотиви як вияв стратегії втечі від тотальності війни.

Ключові слова: Донбас, сучасна українська література, війна в літературі, Любов
\end{abstract} Якимчук.

WAR AS A LITERARY EDITOR:

(PRE)COGNITION OF WAR IN LYUBOV YAKYMCHUK'S

BOOK OF POETRY APRICOTS OF DONBAS

RYSZARD KUPIDURA

Adam Mickiewicz University, Poznań — Poland

\begin{abstract}
The article is devoted to the analysis of Lyubov Yakymchuk's book of poetry Apricots of Donbas published in 2015. The author of the paper argues that the publication of the book fits into the current tendency to increase the representation of the Donbas in contemporary Ukrainian literature. The poems have been read in terms of the construction of time, relationship with tradition and modernity etc. The self-reference tendencies in L. Yakymchuk's poetry were considered separately as a strategy of the escape from the totality of the war.

Key words: Donbas, contemporary Ukrainian literature, war in literature, Lyubov Yakymchuk.

$\mathrm{W}$

literaturze ukraińskiej po 1991 roku zaznaczyła się wyraźna dysproporcja w ilościowej reprezentacji rodzimych miast i regionów. O ile miejska przestrzeń Kijowa i tereny Zachodniej Ukrainy regularnie stawały się pierwowzorami dla literackich kreacji miejsc, o tyle Wschodnia Ukraina, a przede wszystkim Zagłębie Donieckie przez długi czas pozostawało obszarem słabo rozpoznanym i mało obecnym w poezji i prozie. Donbas tradycyjnie uznawany był za ,małą ojczyznę" wybitnych twórców (m.in. Wołodymyra Sosiury, Wasyla Stusa, Emmy Andijewskiej, Iwana Switłycznego, Iwana Dziuby i innych), więź z którą nie deter-
\end{abstract}


minowała w jakiś szczególny sposób ich twórczości. Sytuacja zaczęła znacząco ulegać zmianie w drugiej dekadzie XXI wieku, jeszcze w przededniu wybuchu wojny na tym terytorium. W 2010 roku Serhij Żadan wydaje swój Ворошиловград, trzy lata później czasopismo „Шо” publikuje poemat Lubow Jakymczuk Абрикоси Донбасу, a Ołeksij Czupa kończy swą powieść Бомжі Донбасу, wydaną ostatecznie w $2014 \mathrm{roku}^{1}$. Tworzy się nowy dyskurs reprezentacji industrialnego i postindustrialnego krajobrazu Zagłębia Donieckiego w literaturze ukraińskiej. Poszczególne miejsca na mapie Donbasu stają się przestrzeniami intymnymi, w których bohaterowie literaccy przeżywają swoje dzieciństwo, dojrzewają i zmagają się z problemami dorosłości. Cyrkulacyjny charakter relacji pomiędzy przestrzenią geograficzną a jej literacką reprezentacją sprawia, że ta druga wzmacnia emocjonalny stosunek odbiorców literatury do realnie istniejących miejsc ${ }^{2}$. Jak napisze później - już w czasie działań wojennych - Serhij Żadan: Вона думає, стоячи зранку на своєму місиі, / що навіть ия територія, виявляється, може бути бажаною і дорогою. / Що ї̈, виявляється, не хочеться лишати надовго, / щео за неї, виявляється, хочеться чіплятись зубами, / що для любові, виявлясться, достатньо иъого вокзалу старого / $і$ літньої порожньої панорами ${ }^{3}$.

Obawa o ostateczną utratę wschodnich rubieży kraju jedynie nasiliła opisany powyżej proces. Korpus tekstów, w których reprezentowana jest przestrzeń Donbasu, przyrasta obecnie bardzo intensywnie. Pierwsze próby uchwycenia dynamiki tego procesu pojawiają się w licznych wywiadach $\mathrm{z}$ autorami, recenzjach oraz projektach wydawniczych ${ }^{4}$. Wśród autorów, którzy cieszą się szczególną atencją krytyków i publiczności, wymienić należy przede wszystkim Lubow Jakymczuk. W 2015 roku ukazał się tomik poezji Morele Donbasu ${ }^{5}$, stanowiący podsumowanie ośmioletniego okresu twórczego urodzonej w Perwomajsku poetki.

Marta Studenna-Skrukwa, poznańska badaczka historii Zagłębia Donieckiego, zwraca uwagę, że punktem odniesienia podczas tworzenia pierwszych map politycznych dwudziestowiecznej Ukrainy były dane spisu powszechnego przeprowadzonego w Imperium Rosyjskim w 1897 roku, w których nie uwzględniano narodowości, a głównymi kategoriami podziału ludności były język i wyznanie. „Ukrainą były zatem wszystkie te ziemie, na których ludzie mówiący jakąś formą języka ukraińskiego stanowili większość" - pisze Studenna-Skrukwa ${ }^{6}$. Do 1991 roku, kiedy to ostatecznie ukształtowały się granice współczesnej Ukrainy, ludność tych ziem stała się uczestnikiem szeregu wstrząsów społecznych, takich jak rewolucje, wojny światowe i cały szereg sowieckich eksperymentów z zakresu inżynierii społecznej na czele z przesiedleniami i sztucznie wywołanym głodem. Wszystko to spowodowało,

${ }^{1}$ С. Жадан, Ворошиловград, Харків 2010; Л. Якимчук, Абрикоси Донбасу, [в:] Електронний pecypc: http://sho.kiev.ua/journal/5343 (01.01.2018); О. Чу п а, Бомжі Донбасу, Брустурів 2014; W 2012 roku został wydany również zbiór esejów poświęconych kulturowej ontologii Doniecka: Метафізика Донеиька. Філософські есе, Донецьк 2012.

${ }^{2}$ E. Rybicka, Geopoetyka. Przestrzeń i miejsce we wspótczesnych teoriach i praktykach literackich, Kraków 2014, s. 120.

${ }^{3}$ C. Жадан, Тамплієри, Чернівці 2014, с. 6.

${ }^{4}$ Wśród nich wyróżnia się antologia Породa, w której dobór autorów nie odbywał się według klucza miejsca urodzenia, lecz ze względu na podejmowaną tematykę: Порода: Антологія українських письменників Донбасу, упор. В. Біляв вький, М. Григоров; перед. І. Дзюби, Київ 2017.

5 Л. Якимчук, Абрикоси Донбасу, Львів 2015. W 2018 roku pojawiło się polskie wydanie książki(L. Jaky m c zuk, Morele Donbasu, przeł. A. Kamińska, Poznań 2018), które nie jest pełnym odzwierciedleniem ukraińskiego pierwowzoru. Cytaty z utworów, które nie zostały przetłumaczone, podaję więc $\mathrm{w}$ oryginalnym brzmieniu.

${ }^{6}$ M. S tudenna-Skrukwa, Ukraiński Donbas. Oblicza tożsamości regionalnej, Poznań 2014, s. 128. 
że w warunkach odzyskania niepodległości pojawiła się potrzeba przeglądu definicji konstruktu wyobrażonego, jakim jest ukraińskość i określenia nowych granic jego występowania. Zagłębie Donieckie stało się w tej dyskusji miejscem spornym, wypychanym poza owe granice. W 2010 roku Jurij Andruchowycz w głośnym wywiadzie zaproponował, by nie traktować integralności terytorialnej jako dogmatu i pozwolić oddzielić się od Ukrainy takim regionom jak Krym czy Donieck, jeśli większość ich mieszkańców wyraziłaby chęć przynależności do rosyjskiego kręgu kulturowego i politycznego ${ }^{7}$. W grudniu 2013 Jarosław Hrycak w swoim felietonie uznał Donbas za region, w którym zanikła ostatecznie tradycja kolędowania, przesądzając tym samym o jego sowieckiej tożsamości ${ }^{8}$. Dwa wymienione wyżej teksty po ich publikacjach za każdym razem stawały się przyczynkami do burzliwych dyskusji pomiędzy zwolennikami i przeciwnikami stawianych w nich tez' . Lubow Jakymczuk w przewrotny sposób włącza się do nich geopoetyckim epigrafem swojego tomiku, będącym jednocześnie negatywną definicją Rosji (Tam, gdzie nie rosna morele, zaczyna się Rosja ${ }^{10}$ ). Przy czym symbolika tego florystycznego obrazu odnosi się w poetyce Jakymczuk zarówno do przestrzeni ${ }^{11}$, jak i do jej mieszkańców, w tym kręgu najbliższej rodziny (Танеиь еміграиiï, Morele w kaskach) ${ }^{12}$. Rosja staje się więc figurą obcości, zaczyna się tam, gdzie kończy się intymne i prywatne. „Morele były naszym chlebem powszednim [...] Zbierałyśmy je z siostrą i sprzedawałyśmy konduktorom w moskiewskich pociągach, które zatrzymywały się na naszej stacji. Robiłyśmy konfitury morelowe, kompoty, suszyłyśmy, byle się tylko nie zmarnowały. Smakowały nawet naszemu psu", - mówi w jednym z wywiadów poetka ${ }^{13}$.

Charakterystyczne, że Morele Donbasu otrzymały swą nazwę niejako wbrew intencjom samej autorki. Jak przyznaje w przedmowie Jakymczuk znakowanie jej twórczości „donieckością” było tyleż niechciane dla niej samej, ileż oczywiste dla zewnętrznych obserwatorów. To ich sugestie przeważyły o ostatecznym tytule zbior$\mathrm{ku}^{14}$. Ważne jest to, w jaki sposób poetka uzasadniała swą niechęć wobec afiszowania swych związków z górniczym regionem. Przede wszystkim toponimy Donieck i Donbas, a szczególnie pochodzący od pierwszego przymiotnik doniecki (funkcjonujący zazwyczaj w substantywnej formie) posiadają wciąż jeszcze negatywną konotację i raczej piętnują swego nosiciela, aniżeli otaczają go pozytywną mityczną aurą

\footnotetext{
${ }^{7}$ Андрухович: Якщо переможуть помаранчеві, то Криму й Донбасу треба дати можливість відокремитися, [в:] Електронний ресурс: https://www.unian.ua/politics/382762-andruhovichyakscho-peremojut-pomaranchevi-to-krimu-y-donbasu-treba-dati-mojlivist-vidokremitisya.html (01.01.2018).

8 Я. Грицак, Різдвяне, [в:] Електронний ресурс: https://gazeta.ua/articles/grycak-jaroslav/_ rizdvyane/534035 (01.01.2018).

${ }^{9} \mathrm{Z} \mathrm{J}$. Andruchowyczem poetka prowadzi w Morelach Donbasu bezpośredni dialog, poświęcając mu jeden z cykli, Любов Якимчук: Те, щүо з нами відбувається, і є розкладання: території, мови, людських тіл..., [в:] Електронний ресурс: https://rozmova.wordpress.com/2016/04/04/lubovyakymchuk-3/ (01.01.2018).

${ }^{10}$ L. Jakymczuk, Dz. cyt., s. 10.

11 Jeżeli Jakymczuk znaczy tym obrazem wschodnie rubieże ukraińskiej przestrzeni, to jej zachodnie krańce mógłby wyznaczać współbrzmiący w tym kontekście wiersz Зелена Євангелія Bohdana Ihora Antonycza z jego poetyckim obrazem górskiej wsi położonej wśród morelowych sadów.

${ }^{12} \mathrm{~A}$. Демч ен ко, Художні моделі топосу лому в поетичній збіриі Любові Якимчук „, Абрикоси Донбасу”, [в:] Електронний ресурс: http://litzbirnyk.com.ua/wp-content/uploads/2017/01/21.18.16. $\operatorname{pdf}(01.01 .2018)$.

${ }_{13}$ Любов Якимчук: „Найбільше ображають заклики віддати Донбас”, [в:] Електронний pecypc: https://wz.lviv.ua/interview/133850-liubov-yakymchuk-naibilshe-obrazhaiut-zaklyky-viddatydonbas (01.01.2018).

${ }^{14}$ Л. Якимчук, зазнач. джер., с. VII-VIII.
} 
(jak na przykład galicyjskość), przy czym cezura wojenna nie stała się póki co przełomem katartycznym i nie doprowadziła do zmiany optyki. Do istniejących uprzedzeń doszło jeszcze stygmatyzowanie wojną, co Jakymczuk trafnie oddaje związkiem wyrazowym batalion stereotypó $w^{15}$. Drugi z powodów ma charakter bardziej uniwersalny i wiąże się z odmową przyjęcia statusu „twórcy regionalnego”. Taka postawa jest zrozumiała, jeśli kojarzymy regionalizm z lokalizmem regresywnym, opartym na esencjalistycznej tożsamości, przywiązaniu do ziemi i zakorzenieniu, skutkującym ostatecznie ograniczeniami w doborze środków artystycznych ${ }^{16} . \mathrm{Z}$ drugiej jednak strony, jak wskazuje Elżbieta Rybicka, nowy regionalizm (rozumiany nie tylko jako postawa badawcza, ale i praktyka literacka), ,wychodzi poza partykularyzm, łącząc to, co lokalne bądź regionalne, z tym co światowe" ${ }^{17}$. Ostatnia uwaga wydaje się szczególnie słuszna, kiedy podejmowany jest tak uniwersalny i jednostkowy zarazem problem jak doświadczenie wojny.

Przyglądając się kompozycji zarówno ukraińskiego, jak i polskiego wydania Moreli Donbasu można ulec złudzeniu, że prawdziwą redaktorką literacką w obu przypadkach jest właśnie wojna. Pryzmat wojny nie tylko wpłynął bezpośrednio na podejmowaną tematykę i porządek prezentacji dorobku poetki (bezpośrednio odnoszący się do wydarzeń z lat 2013-2014 cykl Rozkład staje się kulminacją w ukraińskim wydaniu, w polskim natomiast — finałem), ale zdeterminował również jego recepcję. Krytycy nie tylko zaczęli dzielić twórczość Jakymczuk według wojennej cezury $^{18}$, ale także zaczęli pomijać uwagą te teksty, które pozbawione są wojennych metafor lub też odczytywać je w kluczu konfliktu militarnego. Jak pisze Oksana Dowhopołowa: „Świat sprzed wojny staje się widmem, trzeba zmusić się do tego, by uwierzyć w jego istnienie"19. Tak samo przedwojenne wiersze Jakymczuk stają się zamglone i niemalże nieczytelne, zlewając się razem w nieuporządkowane varia. Ich lektura jest uwarunkowana i obciążona wiedzą o tym, co ma za chwilę nastąpić. Wojna tworzy nową perspektywę aksjologiczną. Ważniejsze staje się to, co jest przez nią znaczone. Dotyczy to chociażby liryki miłosnej. Wiersz o rozłące kochanków, spowodowanej przez działania militarne (Brwi), przykuwa więcej uwagi, aniżeli napisany w Polsce utwór Украӥнська мова, traktujący o rodzącym się uczuciu między osobami wywodzącymi się z różnych tradycji kulturowych i wynikającej z tego potrzebie translacji ciała (я хочу перекласти тебе всього украӥнською ${ }^{20}$ ). Gwałt dokonany na kobiecie w warunkach wojennych (Gąsienica) zaciera pamięć o „pokojowej” przemocy domowej (Stalowe przybory, Na wschód od filizanki). W końcu stepowy $i$ industrialny krajobraz, który jeszcze niedawno sam zdolny był postrzegać (Oko hat$d y$ ) i znaczyć ludzkie ciało (A tatko się staje jak trawa-ostnica [...] A policzki jego w bruzdy / porąbata kopalnia ${ }^{21}$ ) w perspektywie wojennej rozpada się i zrywa swe dotychczasowe powiązania z człowiekiem (gdzie moje de bal ce wo? / tam więc nie urodzi się Sosiura / już więcej żaden człowiek nie urodzi sięę2).

15 Tам само, c. VIII.

${ }^{16}$ E. Rybicka, Dz. cyt., s. 335 .

${ }^{17}$ Tamże, s. 348.

${ }^{18}$ Uwagę zwraca fakt, że krytyczka Ołesia Mamczycz przymiotnik ,przedwojenna” ujmuje w nawias. Wydaje się jednak, że jest to wynikiem nie tyle braku wiary w realność wojny, która dotknęła Ukrainę, ile brakiem wystarczającego dystansu czasowego, który uwiarygadniałby użycie takiego określenia, О. Мамчич, Віриі про війну Любові Якимчук, [в:] Електронний ресурс: https:// starylev.com.ua/club/article/virshi-pro-viynu-lyubovi-yakymchuk (01.01.2018).

${ }^{19}$ О. Довгополова, Мануали зі зиивання часу, [в:] А. Достлєв, Окупація (альбом), Б. м. 2017 , с. 48 .

20 Л. Якимчук, зазнач. джер., с. CXII.

${ }^{21}$ L. Jakymczuk, Dz. cyt., s. 25.

${ }^{22}$ Tamże, s. 66. 
Granica między czasem wojny a czasem pokoju rozmywa się ze względu na włączenie do tomiku cyklu Mniam i wojna datowanego na lata 2008-2009. Jego pojawienie się rozrywa ramy chronologiczne realnej wojny, której substancja zaczyna rozlewać się i znaczyć sobą również to, co istniało przed nią. Historia niegrzecznego chłopca, bawiącego się ołowianymi żołnierzykami w wojnę, staje się oczywistym preludium do późniejszych wydarzeń. Już w pierwszym wierszu Mniam wypowiada słowa, które zapowiadają totalny charakter nadchodzącego doświadczenia: Teraz będziesz ogladać sny / a one sa bez reklamy / a pilota zostawię sobie / będe się bawićn ${ }^{23}$. Profetyczna aura, która towarzyszy dzisiejszej lekturze (właśnie lekturze, a nie samym tekstom, które wolne są od proroczej stylisty$\mathrm{ki}^{24}$ ) przedwojennego dorobku Jakymczuk, sprawia, że czytelnik raz za razem posiłkuje się umieszczonymi pod tekstami datami, żeby określić perspektywę czasową podmiotu lirycznego w stosunku do rzeczywistości pozatekstowejej ${ }^{25}$. Zawierający obraz zrujnowanego domu wiersz Popielniczka odbierany jest zazwyczaj jako reakcja poetki na wymuszony przez wojnę wyjazd z rodzinnego regionu, pomimo tego, że został on napisany jeszcze w sierpniu 2013 roku. Może się wydawać, że w tej sytuacji odwrócona została zasada mimesis i to rzeczywistość zaczęła naśladować poezję. Mityczny Bebok (Бабаŭ), którym matka straszy swoje dziecko w wierszu Гортання вій, ożywa i w osobie prawdziwego terrorysty wkracza na donieckie terytorium. „Wojna nigdy nie pojawia się znikąd, najpierw ktoś o niej śni, ktoś się jej boi, toczy wojnę w wyobraźni, fantazjuje o bitwie. Wojna często najpierw pojawia się w kulturze. W książkach i piosenkach, które wyrażają to, co jeszcze niewypowiedziane" - piszą w książce Po północy w Doniecku Grzegorz Szymanik i Julia Wizowska ${ }^{26}$.

Podstawowa różnica pomiędzy przeczuwaniem wojny, a jej obserwowaniem i opisywaniem zawiera się $\mathrm{w}$ tym, że w drugim przypadku autorka uświadamia sobie potrzebę stworzenia nowego języka dla realizacji założonego celu. W przedmowie do zbiorku Jakymczuk pisze: „Nasz język nie jest już taki sam, jakim był do czasu wojny na terytorium Ukrainy lat 2014-201? [...] wojna ingeruje w mowę, a przez nią w język, rozkładając go od środka”27. I dalej: „Wiersze o wojnie mogą być tylko nagie jak druty bez izolacji, bardzo proste i bez nadmiernych zakrętasów, ale i ze ścisłymi szczegółami”"28. Zapowiedź tego, że konflikt militarny radykalnie zmieni język odnajdujemy zresztą już w cyklu Mniam $i$ wojna, w którym to chłopiec czyta słownik niecenzuralnej leksyki / nadaje rzeczom nazwy ze stownika ${ }^{29}$. Wojna — niczym żołnierze na posterunkach — blokuje szlaki obrazowania poetyckiego. Zakorzeniony w rodzimej tradycji sposób metaforyzacji (я полечу великим кольоровим метели$\kappa \mathrm{M}^{30}$ ) staje się niedorzeczny i niemożliwy — między mna a moim ojcem lataja setki pocisków / i nie umiem patrzeć na nie jak na ptaki ${ }^{31}$. Dopiero z czasem język poetki

${ }^{23}$ Tamże, s. 37.

${ }^{24}$ Wyjątkiem jest napisany w czasie przyszłym wiersz skład, w którym poetka wykorzystuje archetyp wody jako symbolu macierzyństwa i powtórnych narodzin w strukturze cyklu mitycznego, А. Демченко, зазнач. джер.; І. Борисюк, Міфологічні мотиви й образи у збіриі „Абрикоси Донбасу” Любові Якимчук, [в:] „Слово і час”, 2016, № 6, с. 36.

${ }^{25} \mathrm{Na}$ potrzebę datowania wierszy pisanych o wojnie zwraca uwagę sama poetka, Любов Якимчук:

Те, що з нами відбувається... зазнач. джер.

${ }^{26}$ G. Szymanik, J. Wizowska, Po pótnocy w Doniecku, Warszawa 2016, s. 7.

${ }^{27}$ Л. Яки мчук, зазнач. джер., с. Х.

${ }^{28}$ L. Jakymczuk, Dz. cyt., s. 90.

${ }^{29}$ Tamże, s. 38.

${ }^{30}$ Л. Якимчук, зазнач. джер., с. XLIII.

${ }^{31}$ L. Jakymczuk, Dz. cyt., s. 65. 
nabiera odpowiedniej tonacji i zaczyna poddawać się poetyce rozkładu — patrzy jak gasienica dożera ich zielone miasto ${ }^{32}$.

Badacze zajmujący się wpływem konfliktów zbrojnych na społeczeństwa podkreślają, że doświadczenie wojenne powoduje proces rozpadu konstruktów społecznych na części i rozrzedzenie podstawowych wartości wspólnotowych ${ }^{33}$. Jakymczuk w wierszu Rozkład pokazuje, że proces ten ma totalny charakter i dotyczy wszystkich innych aspektów ludzkiej egzystencji, w tym — ciała, języka i przestrzeni.

Poetka, konsekwentnie odżegnująca się od statusu regionalnego autora, podejmuje $\mathrm{w}$ tomiku dialog $\mathrm{z}$ rodzimą tradycją kluczową (w rozumieniu zaproponowanym przez Janusza Sławińskiego ${ }^{34}$ ), którą w ukraińskiej sytuacji stanowi twórczość romantyka Tarasa Szewczenki (mój pierwszy wiersz o Szewczence). Jednak dialog ten - jak wszystko w tych okolicznościach — warunkowany jest przez bieżącą sytuację społeczno-polityczną, która sprawia, że przestrzenią dla rozmowy staje się „tu i teraz". To Szewczenko dokonuje podróży w czasie, przychodząc na współczesny Majdan. Chore od zimna i bezsenności protestujące społeczeństwo przyjmuje swojego wieszcza jak lekarstwo razem z biseptolem i witaminą C. Dawka poety, jaką aplikuje sobie i innym Jakymczuk, stanowiąca wprzód czytelne nawiązanie do okrągłej rocznicy urodzin autora Hajdamaków, wraz z upływem czasu nabiera nowych, tanatycznych znaczeń. Zwróćmy uwagę, że poetka używa jego nazwiska nie w celowniku, lecz w mianowniku (Szewczenko 200 ${ }^{35}$ ), co multiplikuje możliwość potencjalnych interpretacji. Kilka miesięcy po napisaniu wiersza liczba 200 stanie się liczbą traumatyczną ze względu na aktualizację radzieckiej tradycji oznaczania nią ciał poległych w boju żołnierzy („ładunek 200”). Zestawienie „Szewczenko 200” w parze z Niebiańską Sotnią i przyszłymi ofiarami wojny rosyjsko-ukraińskiej przyobleka Szewczenkowski mit w nowe konteksty znaczeniowe, wzmacniając go o siłę Korczakowskiego gestu.

Jakymczuk została nazwana przez krytyków kronikarzem czasu wojennego ${ }^{36}$. Należy jednak zauważyć, że jej kronikarska narracja charakteryzuje się — jeśli odwołać się do badań nad konstrukcją czasu w utworach epickich - wąskim horyzontem czasowym ${ }^{37}$. To perspektywa bieżącej relacji, swoistego współobserwowania i współodczuwania z kreowanymi postaciami. Pojawiające się w twórczości ukraińskiej poetki topografie (bruk na Hruszewskiego, dom związów zawodowych ${ }^{38}$ ) stanowią arenę rewolucyjnych wydarzeń i jeszcze „nie zdążyły” przekształcić się w miejsca pamięci. W twórczości poetki mobilizowana jest bowiem nie tyle pamięć, ile zdolność do rejestracji i zapamiętywania. Cykl poetycki Rozkład to uważne przyglądanie się temu, co dzieje się z rzeczywistością, językiem i ciałem w obliczu wojny jako po foucaultowsku rozumianej heterochronii. Dezintegrujący efekt znalezienia się w orbicie oddziaływania wojny jest nieuchronny niezależnie od tego, czy pojawiają się w jej sąsiedztwie epitety mające pozornie zmiękczyć jej totalny wy-

${ }^{32}$ Tamże, s. 71 .

${ }^{33} \mathrm{O}$. Су ш й й, Проблема колективної травми в українському соиіумі та пошук стратегій їі опанування, [в:] Електронний ресурс: http://www.ipiend.gov.ua/uploads/nz/nz_74/sushyi_problema. pdf (01.01.2018).

${ }^{34}$ J. S ław iń s ki, Synchronia i diachronia w procesie historycznoliterackim, [w:] Te g o ż, Dzieła. Język. Tradycja, Warszawa 1974, s. 28.

${ }^{35}$ L. Jakymczuk, Dz. cyt., s. 58.

${ }^{36}$ Г. Сафроньє ва, Донбас як абрикосова кісточка, [в:] Електронний ресурс: https://zbruc. eu/node/38961 (01.01.2018).

${ }^{37}$ K. Bartoszyński, Problem konstrukcji czasu $w$ utworach epickich, [w:] Problemy teorii literatury, wyb. H. Markiewicz, Wrocław 1987, t. 2, s. 253.

${ }^{38}$ L. Jaky mczuk, Dz. cyt., s. 53, 57. 
miar (niewypowiedziana wojna, wojna hybrydowa etc.). Pierwsze próby wybudowania pewnego dystansu do traumatycznych wydarzeń, a wraz z nimi rozszerzenie horyzontu czasowego pojawiają się dopiero w najpóźniej datowanych wierszach. $\mathrm{W}$ utworze Повернення z 2015 roku po raz pierwszy daje znać o sobie tęsknota za utraconym domem i charakterystyczne w takiej sytuacji pragnienie zajrzenia do albumu rodzinnego, tego szczególnego artefaktu pamięci, który ma stać się zarówno materialnym, jak i symbolicznym łącznikiem z przeszłością̧

Schronienie przed napierającą zewsząd i skupiającą na sobie uwagę tematyką wojenną może dać jedynie ucieczka od tematu jako takiego i zwrócenie się ku autotelicznym funkcjom literatury. Te zabiegi można odczytywać jako zmaganie się literatury z wojną, niezgodę tej pierwszej na bycie zawłaszczoną przez drugą. Wojna nie ma wstępu tam, gdzie literatura zajmuje się sama sobą. Autotematyczne tendencje w poezji Jakymczuk najwyraźniej zaznaczyły się w wierszu Suszona morela, w którym akt twórczy przyrównany zostaje do procesu gnicia lub zasuszania owocu. Innym interesującym przypadkiem jest utwór Це не чек, це віри. Sytuację, w której paragon sklepowy z błędnie wydrukowaną wróżbą otrzymuje rangę tekstu poetyckiego, można by uznać za żart poetki nie wytrzymujący zderzenia nawet $\mathrm{z}$ awangardowymi definicjami wiersza. Jeśli nawet tak jest, to nie zmienia to faktu, że Jakymczuk prowokuje czytelnika do refleksji nad zapomnianymi już trochę dzisiaj zagadnieniami z zakresu statusu dzieła literackiego i jego autora. Gdy stawiamy pytanie o to, w którym momencie i z czyjej woli paragon z wróżbą stał się literaturą, to odpowiedź uzyskamy wówczas, kiedy zwrócimy uwagę na sposób, w jaki przeczytała go Jakymczuk. Jest to sposób, który — jak to określił Jonathan Culler - pozwala rozpoznać tekst literacki pośród pozostałych tekstów nieliterackich na tej samej zasadzie, na której ogrodnik dokonuje selekcji pomiędzy chwastami a niechwastami ${ }^{40}$. Lubow Jakymczuk czyta paragon w trzech hipostazach jako: a) czytelnik właściwy, czyli ten, który za Daniiłem Elkoninem odtwarza dźwiękową formę słowa na podstawie jego obrazu graficznego ${ }^{41}$; b) poetka; c) historyk literatury. Doświadczenie trzeciej postaci będzie miało tutaj szczególne znaczenie, gdyż to właśnie badanie spuścizny ukraińskiego futuryzmu, pozwoliło poetce nie tylko przeczytać, ale i zobaczyć w paragonie wiersz. Obcowanie z wizualną poezją Mychajła Semenki poszerzyło konwencjonalne wyobrażenie poetki na temat tego, czym jest i czym może być literatura i zachęciło ją do tego, by dostrzegać ślady poezji w najbardziej nawet zinstrumentalizowanych tekstach technicznych ${ }^{42}$. Urwana w pół słowa wróżba (Будbme $л ю \sigma^{43}$ ) stała się w ten sposób logiczną kontynuacją cyklu poetyckiego poświęconemu problemowi rozpadu języka. Za datę powstania wiersza należy więc uznać nie tę odmierzoną co do sekundy, która widnieje na paragonie, lecz moment lektury paragonu przez Jakymczuk. Jej koniec, uwieńczony diagnozą (Це не чек, це віри), jest właściwym momentem powstania utworu. Lekturę, która zmienia status tekstu na literacki możemy zatem nazwać lektura sprawcza lub pojetyczną.

${ }^{39}$ Л. До стлєв а, Про (не)можливість реконструкиії сімейного архіву, [в:] А. До стлє в, зазнач. джер., с. 65.

${ }^{40} \mathrm{~J}$. Culler, Co to jest literatura i czy pytanie to ma jakiekolwiek znaczenie?, [w:] Tego ż, Teoria literatury, przeł. Maria Bassaj, Warszawa 1998, s. 31.

${ }^{41}$ Д. Эльконин, Этапы формирования действия чтения: Фонемный анализ слов, [в:] Электронный ресурс: http://pedlib.ru/Books/3/0157/3_0157-1.shtml (01.01.2018).

${ }^{42}$ J. Culler, Dz. cyt., s. 46. Podobnych eksperymentów, jawnie odwołujących się do tradycji ukraińskiego futuryzmu znajdujemy w tomiku więcej, np. Годинник, Вірм із родзинками i inne.

${ }^{43}$ Л. Яки ич ук, зазнач. джер., с. LXXIX. 
Były już wojny i byli już poeci, którzy pisali lub milczeli o nich — mówi Lubow Jakymczuk $^{44}$. Jednak nie oznacza to tego, że w obliczu zetknięcia z nią poeta może sięgać do rezerwuaru tradycji. Za każdym razem trzeba zaczynać wszystko od początku, szukać nowej formy i nowego rytmu. Przed takim niełatwym zadaniem znalazła się większość ukraińskich twórców, należących do różnych generacji i prezentujących różne style poetyckie i prozatorskie. Wojna ,redaguje” nie tylko pojedyncze tomiki poezji, ale wskazuje również kierunki rozwoju procesu historycznoliterackiego. Lata 2013-2014 stanowią cezurę nie tylko w najnowszej historii politycznej Ukrainy, ale również otwierają nowy okres w historii jej literatury. Nie znamy jeszcze pełnych ram czasowych tego okresu. Niezależnie jednak od tego, kiedy się on zakończy, twórczość Lubow Jakymczuk będzie stanowiła w nim ważny element, odznaczający się szeregiem wyróżników poetyckich. Najlepiej mówi zresztą o nich sama poetka: моя пісня інакша / може, трохи з присмаком сажі / але тепла, як вугілля Донбасу ${ }^{45}$.

\section{Wykaz wykorzystanej literatury}

Андрухович: Якщз переможуть помаранчеві, то Криму й Донбасу треба дати можливість відокремитися, [в:] Електронний ресурс: https://www.unian.ua/politics/ 382762-andruhovich-yakscho-peremojut-pomaranchevi-to-krimu-y-donbasu-treba-datimojlivist-vidokremitisya.html (01.01.2018).

Борисюк І., Міфологічні мотиви й образи у збіриі „,Абрикоси Донбасу” Любові Якимчук, [в:] „Слово і час”, 6/2016, с. 34-41.

Грицак Я., Різдвяне, [в:] Електронний ресурс: https:/gazeta.ua/articles/grycak-jaroslav/_ rizdvyane/534035 (01.01.2018).

Демченко А., Художні моделі топосу лому в поетичній збіриі Любові Якимчук „Абрикоси Донбасу”, [в:] Електронний ресурс: http://litzbirnyk.com.ua/wp-content/ uploads/2017/01/21.18.16.pdf (01.01.2018).

Довгополова О., Мануали зі зиивання часу, [в:] А. Достлєв, Окупачія (альбом), Б. м. 2017.

Достлєва Л., Про (не)можливість реконструкції сімейного архіву, [в:] А. Достлєв, Окупація (альбом), Б. м. 2017.

Жадан С., Тамплісри, Чернівці 2014.

Мамчич О., Вірші про війну Любові Якимчук, [в:] Електронний pecypc: https://starylev. com.ua/club/article/virshi-pro-viynu-lyubovi-yakymchuk (01.01.2018).

Сафроньєва Г., Донбас як абрикосова кісточка, [в:] Електронний ресурс: https://zbruc. eu/node/38961 (01.01.2018).

Любов Якимчук: „, Найбільше ображають заклики віддати Донбас”, [в:] Електронний pecypc: https://wz.lviv.ua/interview/133850-liubov-yakymchuk-naibilshe-obrazhaiutzaklyky-viddaty-donbas (01.01.2018).

Любов Якимчук: Те, що з нами відбувається, і є розкладання: території, мови, людських тіл..., [в:] Електронний ресурс: https://rozmova.wordpress.com/2016/04/04/ lubov-yakymchuk-3/ (01.01.2018).

Bartoszyński K., Problem konstrukcji czasu w utworach epickich, [w:] Problemy teorii literatury, wyb. H. Markiewicz, Wrocław 1987, t. 2, s. 253.

Culler J., Co to jest literatura i czy pytanie to ma jakiekolwiek znaczenie?, [w:] Tegoż, Teoria literatury, przeł. Maria Bassaj, Warszawa 1998.

Jakymczuk L., Morele Donbasu, przeł. A. Kamińska, Poznań 2018.

Rybicka E., Geopoetyka. Przestrzeń $i$ miejsce we współczesnych teoriach i praktykach literackich, Kraków 2014.

\footnotetext{
${ }^{44}$ Там само, с. X.

45 Там само, с. CLXVII.
} 
Sławiński J., Synchronia i diachronia w procesie historycznoliterackim, [w:] Tegoż, Dzieła. Język. Tradycja, Warszawa 1974.

Studenna-Skrukwa M., Ukraiński Donbas. Oblicza tożsamości regionalnej, Poznań 2014.

Szymanik G., Wizowska J., Po pótnocy w Doniecku, Warszawa 2016.

\section{Wykaz wykorzystanej literatury [References]}

Andrukhovych: Yakshcho peremozhut pomaranchevi, to Krymu y Donbasu treba daty mozhlyvist vidokremytysia [If Orange Win, Crimea and Donbas should be Given Opportunity to Separate], [v:] Elektronnyi resurs: https://www.unian.ua/politics/382762andruhovich-yakscho-peremojut-pomaranchevi-to-krimu-y-donbasu-treba-datimojlivist-vidokremitisya.html (01.01.2018).

Borysiuk I., Mifologichni motyvy i obrazy u zbirtsi „Abrykosy Donbasu” Liubovi Yakymchuk [Mythological Motives and Offence in "Apricots of Donbas"], [v:] „Slovo i chas”, 6/2016, s. 34-41.

Hrytsak Ya., Rizdviane [Chrismas], [v:] Elektronnyi resurs: https://gazeta.ua/articles/grycakjaroslav/_rizdvyane/534035 (01.01.2018).

Demchenko A., Khudozhni modeli toposu lomu v poetychnii zbirtsi Liubovi Yakymchuk „Abrykosy Donbasu" [Fiction Models of Topos in Collection of Works by Liubov Yakymchuk "Apricots of Donbas" ], [v:] Elektronnyi resurs: http://litzbirnyk.com.ua/wp-content/ uploads/2017/01/21.18.16.pdf (01.01.2018).

Dovhopolova O., Manualy zi zshyvannia chasu [Manuals of Sewing Time], [v:] A. Dostliev, Okupatsiia (albom), B. m. 2017.

Dostlieva L., Pro (ne)mozhlyvist rekonstruktsii simeinoho arkhivu [About Impossibility of Family Archives Reconstruction], [v:] A. Dostliev, Okupatsiia (albom), B. m. 2017.

Zhadan C., Tampliiery, Chernivtsi 2014.

Mamchych O., Virshi pro viinu Liubovi Yakymchuk [Poetry about War by Liubov Yakymchuk], [v:] Elektronnyi resurs: https://starylev.com.ua/club/article/virshi-pro-viynu-lyuboviyakymchuk (01.01.2018).

Safronieva H., Donbas yak abrykosova kistochka [Donbas as Apricot Stone], [v:] Elektronnyi resurs: https://zbruc.eu/node/38961 (01.01.2018).

Yakymchuk Liubov: „Naibilshe obrazhaiut zaklyky viddaty Donbas” [To give away Donbas, these Claims Offence the most], [v:] Elektronnyi resurs: https://wz.lviv.ua/ interview/133850-liubov-yakymchuk-naibilshe-obrazhaiut-zaklyky-viddaty-donbas (01.01.2018).

Yakymchuk Liubov: Te, shcho z namy vidbuvaietsia, i ye rozkladannia: terytorii, movy, liudskykh til...[This what's going on with us is Stealing The Territory, Language and Human Bodies...], [v:] Elektronnyi resurs: https://rozmova.wordpress.com/2016/04/04/lubovyakymchuk-3/ (01.01.2018).

Bartoszyński K., Problem konstrukcji czasu w utworach epickich, [w:] Problemy teorii literatury, wyb. H. Markiewicz, Wrocław 1987, t. 2, s. 253.

Culler J., Co to jest literatura i czy pytanie to ma jakiekolwiek znaczenie?, [w:] Tegoż, Teoria literatury, przeł. Maria Bassaj, Warszawa 1998.

Jakymczuk L., Morele Donbasu, przeł. A. Kamińska, Poznań 2018.

Rybicka E., Geopoetyka. Przestrzeń i miejsce we wspótczesnych teoriach i praktykach literackich, Kraków 2014.

Sławiński J., Synchronia i diachronia w procesie historycznoliterackim, [w:] Tegoż, Dzieła. Język. Tradycja, Warszawa 1974.

Studenna-Skrukwa M., Ukraiński Donbas. Oblicza tożsamości regionalnej, Poznań 2014.

Szymanik G., Wizowska J., Po pótnocy w Doniecku, Warszawa 2016. 